\title{
Characterization and evaluation of nanocomposites chitosan-multiwalled carbon nanotubes as broad-spectrum antibacterial agent
}

\author{
Nahla El-Tohamy ${ }^{1}$, M Attia $^{2}$, Saadia M Easa ${ }^{1}$ and Nemat M Awad ${ }^{2}$ \\ ${ }^{1}$ Microbiology Department, Faculty of Science, Ain Shams University \\ ${ }^{2}$ Agricultural Microbiology Department, National Research Centre, Dokki, Cairo, Egypt
}

\begin{abstract}
Due to the wide and inappropriate use of the antibiotics, the development of new resistant strains of bacteria to the most of common antibiotics has become a serious problem in public health; so there is a strong stimulant to continuity developing new and effective antimicrobial agents. Nanotechnology considers as a magic tool to explore and treat the difficult problems of medical sciences. The confluence of nanotechnology and microbiology solves several biomedical problems, and also can revolutionize the health and medicine fields.

Recently reports prove that carbon-based nanomaterials like multiwalled carbon nanotubes (MWCNTs) show potent antimicrobial properties. The nanocomposite chitosan-multiwalled carbon nanotube $(\mathrm{Ch} / \mathrm{MWCNT})$ was synthesized by the process of sonication for $20 \mathrm{~min}$ and examined their antibacterial activity.

Seven different concentrations of MWCNT were used in the preparation of Ch/MWCNT (from 5 to $100 \mathrm{mg}$ ). The prepared differently concentrated MWCNT nanocomposite was characterized using TEM and FTIR. According to TEM results which showed that the morphology of MWCNTs were obtained in the form of small tubes of a length. FTIR show that the presence of the $\mathrm{C}=\mathrm{C}$ absorption at the wave number $2344 \mathrm{~cm}^{-1}$ which confirm the successful incorporation between chitosan and MWCNT.

For antimicrobial activity estimation, the serial dilution method was used towards Gram positive bacteria (Staphylococcus aureus NRC 23516, Methicillin-resistant Staphylococcus aureus (MRSA) NRC 629012) and Gram negative bacteria (Escherichia coli 0157H7 and Pseudomonas aeruginosa ATCC10145). The composite $\mathrm{Ch} / \mathrm{MWCNT}$ showed higher antimicrobial activity against both Gram negative and Gram positive bacteria; P. aeruginosa, Staphylococcus aureus; respectively with increasing MWCNT concentrationtill ratio 1:4. The nanocomposites are highly differentiable at the low concentration; $1 \%$ concentration of the multifunctional nanocomposite is very effective against the tested microbes. Minimal inhibitory concentrations (MIC) of $\mathrm{Ch} / \mathrm{MWCNT}$ (100:50 Ch/MWCNT) against Gram negative and Gram positive pathogenic bacteria between 0.5 and $0.0625 \mu \mathrm{g}$, and the growth inhibition effect was observed in a concentration-dependent species.
\end{abstract}

Keywords: Chitosan; Carbon nanotube; antimicrobial activity

Corresponding Author : nahlael2hamy@yahoo.com 


\section{Introduction:}

Nanotechnology undergoes a rapid development in many various fields, especially microbiology and infectious diseases. Recently microbial resistance to antibacterial and antifungal drugs reaches a critical level, which reflecting on the therapeutic effectiveness of a large proportion of currently used drugs (Fair and Tor, 2014).

Anitibiotics abuse is one of the greatest obstacle facing doctors especially for intensive care patients. Mortality rate in intensive care unit (ICU) patients with bacterial based diseases are continues increasing in the last years when antibiotics are not enough. Antibiotics which can be lifesavers, but the overuse and misuse increase the number of drug-resistant germs. As microorganisms develop their resistance toward different antibiotics, the needs to discover and investigate newly antimicrobial agents are also increase. Some microbial infections cause critical risk to human life such as chronic obstructive pulmonary disease, which considers as the fourth leading cause of death in the United States Sethi and Murphy (2001). By using nano medicine which is applying nanotechnology in the health and medicine; early detection, accurate diagnosis, favorable treatment and control of diseases is possible (Kumar. et al., 2008).

The antibacterial properties of nanoparticles of copper, silver, $\mathrm{ZnO}, \mathrm{CuO}$ and carbon nanotube (CNT) have examined by Akhavan, et al., (2011).CNT and its composites recently get much attention, due to their unique distinctive properties such as magnetic and mechanical strength, high thermal and electrical conductivity, high thermal and chemical stability, and high surface area which are much useful for several applications.

Since the beginning of the 21st century, applications of CNT increase in various fields including tissue engineering, wound dressing and gene and drug delivery. Also CNT enters in extraction and analysis of drugs and pollutants. Moreover, CNT is considered as antioxidant for health protective effect. Inlay CNT with low metal content possess strong antimicrobial activity (Kang et al., 2007).

The usage of CNT as antimicrobial agent is limited due to the low dispersion of CNT. Also to avoid the direct contact of CNT aggregates which cause cell damage, finally leading to cell death (Amiri etal., 2012). Chemical purification or functionalization of CNT can change the CNT physiochemical properties to be more dispersive and easily to dissolve in various solvents (Kang et al., 2008).

For CNTs progressing, CNT dispersibility must be increased to can reach the optimal strength or conductivity properties. Chemical functionalization of CNT improved its properties such as developing the antimicrobial activity and decreasing the toxicity toward mammalian cells. Chemical attachment of epilson - poly lysine with CNT improved antimicrobial activities against E. coli, Pseudomonas aeruginosa and S. aureus (Aslan et al., 2013). In the dark nanocomposite of Silver - CNT has been showed strong antibacterial activity against E. coli (Akhavan et al., 2011).

Chitosan $(\mathrm{Ch})$ is a natural polymer and most important derivative of chitin. Chitosan is a linear polysaccharide; and considers as the second most bountiful natural polysaccharide in the 
universe after cellulose. Chitosan can be extracted from insects, cell wall of fungi, and mainly isolates from marine waste of crustacean shells and shrimps (Piresa et al., 2014).

Chitosan commercial interest arises from its fact of having adorable biological characteristics allow for a wide variety of applications including biodegradability, biocompatibility, nontoxicity, biomedical, gel-forming ability, high adsorption capacity and its antimicrobial properties (Mokhena $\boldsymbol{e t}$ al., 2015).

Chitosan and its derivatives have various applications in several fields as in biotechnology, agriculture, food processing, chemistry, medicine, cosmetics, dentistry, textiles, environmental sciences, as well as a safe incipient in drug formulation over the last years (Duttagupta et al., 2015).

The first study examined chitosan for its high inactivation rate against Gram-positive and Gramnegative bacteria, filamentous fungi and yeast was in 1979. Since then, many other studies on chitosan antimicrobial properties and its derivatives have reported (Lee and Je, 2013). Chitosan is considered as a desirable antimicrobial polymer for numerous industrial applications due to its easily and abundant availability, long-term storage stability, it does not decompose or emit toxic products, it is nontoxic and is not irritating toward mammalian cells (Pandey et al., 2017).

Although the amazing chitosan properties as its ability to provide anon-protein matrix for tissue growth, renewable biocompatible and biodegradable polysaccharide considering it to be an ideal material in the biomedical field. However, chitosan has poor mechanical properties which limit its applications. In order to improve $\mathrm{Ch}$ advantages, chitosan combined with different polymers and fillers producing a variety of chitosan-based nanocomposites with advanced properties (Piresa et al., 2014)..

In this study, we prepared a series of $\mathrm{Ch} / \mathrm{MWCNT}$ and checked them for antimicrobial activity against human pathogen Gram negative and Gram positive bacteria. Our master goal of this study is to combine the antimicrobial activity of both of chitosan and MWCNT in order to design broad spectrum biocompatible antimicrobial biomaterials.

\section{Materials and Methods:}

\subsection{Materials:}

Carbon nanotubes were received from (Beni-Sueif University, Faculty of Advanced Science). $\mathrm{HNO}_{3}(67 \%)$ and $\mathrm{H}_{2} \mathrm{SO}_{4}(98 \%)$ were purchased from Nen Tech Ltd. BrixworthNorthants. U.K.Chitosan was purchased from Mallinckrodt, USA [M.W $=400,000$, degree of deacetylation 95\%].

All used glassware were rinsed with $10 \% \mathrm{HNO}_{3}$, to remove all impurities that may be present and to prevent further adsorption of heavy metals to the walls of the glassware, wash three times with deionized water and kept clean and dry for use.

\subsection{Purification of CNT:}

Cutting and purification of the CNTs was carried out using a modified literature procedure. The CNTs (500 mg) were added to a mixture of $98 \% \mathrm{H}_{2} \mathrm{SO}_{4}$ and $65 \% \mathrm{HNO}_{3}(\mathrm{~V}: \mathrm{V}=3: 1,200 \mathrm{~mL}$ ) and exposed to sonic irradiation at $25{ }^{\circ} \mathrm{C}$ for $30 \mathrm{~min}$. 
The cut CNTs were thoroughly washed with ultra pure water and filtered through a micro-porous filtration membrane. They were re-dispersed in $\mathrm{HNO}_{3}(2.6 \mathrm{M}, 200 \mathrm{~mL})$ and refluxed for $24 \mathrm{hrs}$, collected by filtration and washed with ultra pure water to neutrality. The product was then dried under vacuum at 50 ${ }^{\circ} \mathrm{C}$ for $24 \mathrm{hrs}$.

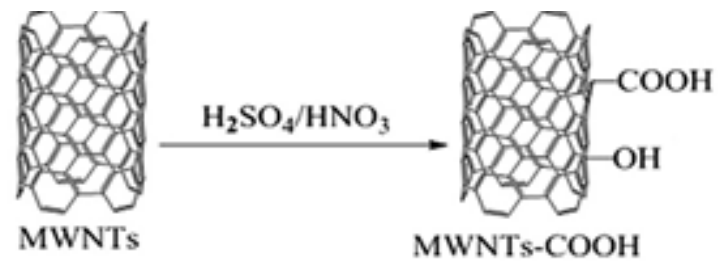

Figure 1: Purification of MWCNT

\subsection{Preparation of Chitosan-CNT:}

Different amounts of Cut CNTs were sonicated in chitosan solution (40 mg in $0.1 \mathrm{M}$ aqueous acetic acid, $40 \mathrm{~mL}$ ) for $20 \mathrm{~min}$ and then stirred at room temperature for $8 \mathrm{~h}$. The modified MWCNTs were collected and washed with ultra pure water by ultracentrifugation to remove unbound Chitosan, then collected and dried at room temperature to obtain $\mathrm{Ch} / \mathrm{MWCNTs}$ with different CNT concentrations for CNT5, CNH10, CNH25, CNH50 and CNT100; 5, 10, 25, 50 and $100 \mathrm{mg}$ of CNT were used, respectively(Kang et al., 2007).

\subsection{Methods used for structural characterization:}

\subsubsection{Morphological analysis:}

The morphological analysis of the modified MWCNT and its chitosan nanocomposites were investigated by transmission electronic microscopy (TEM), where the TEM images were obtained by (JEM-1230-electron microscopy operated at $60 \mathrm{KV}$ ). Before taking a TEM image the sample was diluted at least 10 times by water. A drop of well dispersed diluted sample was placed onto a copper grid (200 mesh and covered with a carbon membrane) and dried at ambient temperature (Kang et al., 2008).

\subsubsection{Fourier transforms infra-red spectroscopy (FT-IR):}

FTIR spectra of the chitosan and the nanocomposites of modified MWCNTs/chitosan recorded on a FTIR spectrophotometer (Thermo Nicolet, NEXUS, TM) in the range of 4000-400 cm-1 using $\mathrm{KBr}$ pellets.

\subsection{Antimicrobial study:}

\subsubsection{Microorganisms used :}

The following pathogenic bacteria were used as indicator microorganism in all assays for determination of the activation of chitosan, CNT and their derivatives (1, 5, 10, 25 and $50 \mathrm{CNT})$ as broad-spectrum antibacterial. The test organisms, namely included, the bacteria Gram negative bacteria (Escherichia coli O157H7 and Pseudomonas aeruginosa ATCC10145) and Gram positive bacteria (Staphylococcus aureus NRC 23516 and Methicillin-resistant Staphylococcus aureus (MRSA) NRC 629012). All of them were obtained from the culture collection in the Department of Agricultural Microbiology, National Research Centre, Cairo, Egypt. 


\subsubsection{Preparation of bacterial inoculums:}

All test bacteria were grown in Luria-Bertani (LB) broth medium (Sambrook et al., 1989) and incubated at $37{ }^{\circ} \mathrm{C}$ for $24 \mathrm{hrs}$ and a total of $10 \mathrm{ml}$ of the pure culture was centrifuged to pellet out the cells, washed twice with sterile physiological saline solution and the suspension was adjusted to optical density 0.1 at $600 \mathrm{~nm}$ which is equivalent to a cell population of about $10^{6}$ cells $/ \mathrm{ml}$ on the McFarland standard. Bacteria suspension was stored in test tubes in a refrigerator at $4{ }^{\circ} \mathrm{C}$. These test bacteria were frequently checked for viability and prepared when appropriate.

\subsubsection{Antibacteial activity test:}

Antibacterial activity test was performed using disc diffusion method (Mostafa et al., 2018). LB agar plates were prepared, sterilized and solidified. After solidification, pathogenic microorganisms cultures were swabbed on these plates. The sterile discs were dipped in the chitosan compoundsand placed on the surface of the agar plates and kept for incubation at $37^{\circ} \mathrm{C}$ for $24 \mathrm{hrs}$. The diameter of zone of inhibition was measured. The negative control treats with solvent (acetic acid) and positive control with Nalidixic acid. The experiments were repeated thrice and mean values of zone diameters were recorded. Compound showing promising activities was selected for further studies.

\subsubsection{Minimal inhibitory concentrations (MIC):}

MIC was performed using serial dilution method (Ruangpan L., 2004). Approximately $1 \mathrm{mg}$ of the selected promising activity Ch-MWCNT nanocomposite was weighted and dissolved in $100 \mu$ of $100 \%$ acetic acid. A stock solution was diluted to concentration of 1:2, 1:4, 1:8 and 1:16, each tested in triplicate, respectively. With a precision delivery system, prepunched, absorbent paper disks (6 mm) were individually impregnated with $10 \mu \mathrm{l}$ of each concentration of the selected promising activity Ch-MWCNT agent. The disks were immediately subjected to rapid drying and then placed in vials containing LB broth medium inoculated with tested pathogenic organisms and incubated at $37{ }^{\circ} \mathrm{C}$ for $24 \mathrm{hrs}$. The minimum inhibitory concentration (MIC) was regarded as the lowest concentration of the Ch-MWCNT required to completely inhibit bacterial growth after incubation at $37^{\circ} \mathrm{C}$ for 24 hours.

\subsection{Statistical analysis:}

All the experiments were carried out in five replicates and mean values were presented. The data presented in graphs and tables corresponding to mean values + SEM and the statistical significant $(\mathrm{P}<0.05)$ was established by using SPSS Version 12.0, Chicago, USA software program.

\section{RESULTS AND DISCUSSION:}

\subsection{Purification of MWCNT:}

Purification of MWCNT was examined by investigation the presence of carboxylic group in the modified MWCNT, this investigation was done through FTIR analysis and also through esterification reaction where the ester odour was evolved by immersion of modified MWCNT in alcohol and addition of few drops from concentrated $\mathrm{H}_{2} \mathrm{SO}_{4}$.

\subsection{Morphological analysis:}

The morphology of MWCNT and its chitosan nanocomposite was investigated using TEM 
analysis as shown in Figure (2). From the figure, it is clear that, there is a noticeable homogeneity between the modified MWCNT and the chitosan polymer in the nanocomposite composed of 100 chitosan : 50 CNT. From the figure, it is also obvious that, the modified MWCNT has a good distribution over the chitosan polymer surface. This result confirms the successful preparation of MWCNT/Chitosan nanocomposite.
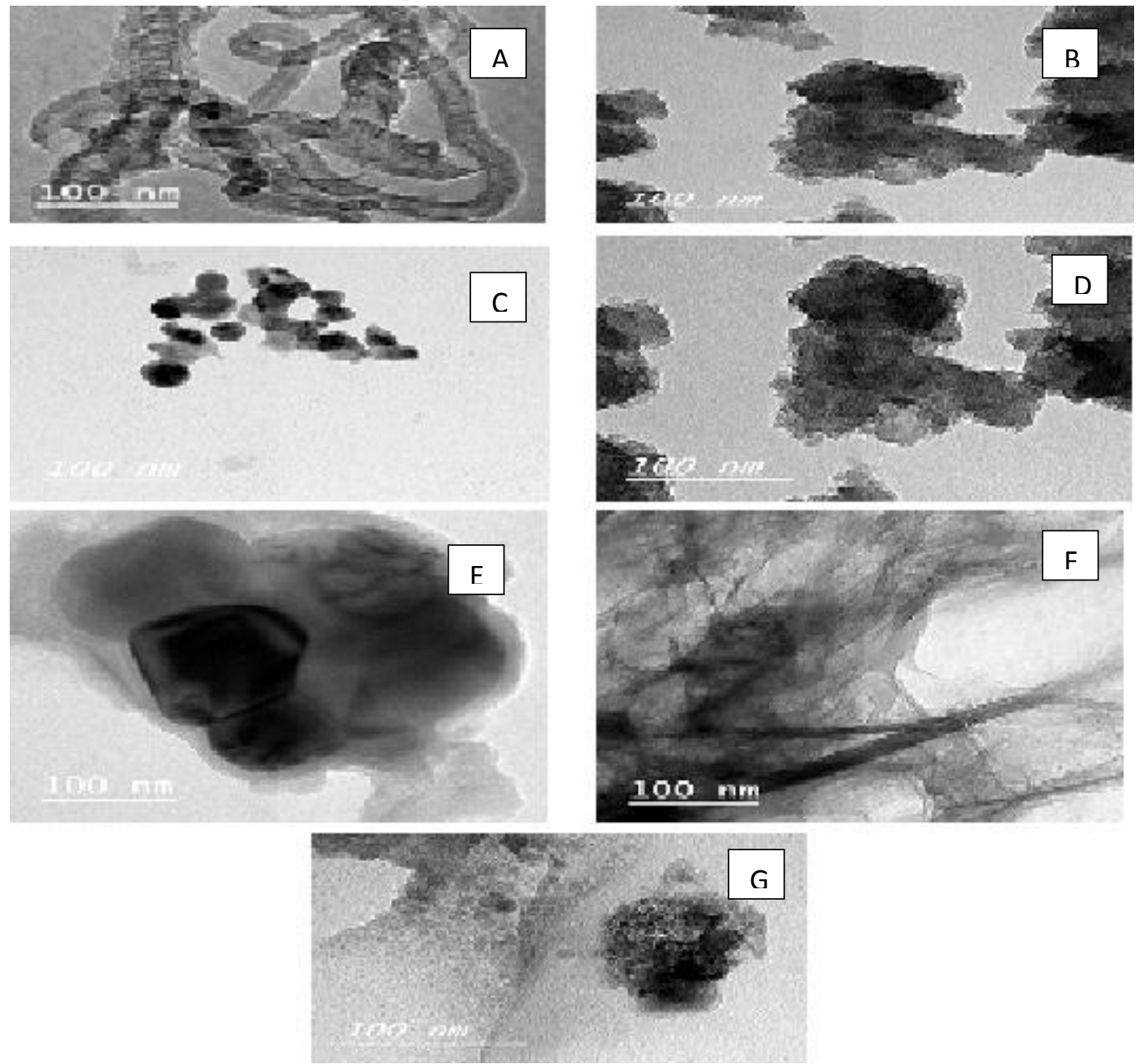

Figure (2): TEM imaged for modified MWCNT and modified MWCNT/Ch nanocomposite where A) 100CNT, B)100Ch, C)100Ch:1CNT, D)100Ch:5CNT, E)100Ch:10CNT, F) $100 \mathrm{Ch}: 25 \mathrm{CNT}$ and G)100Ch:50CNT

\subsection{Fourier transforms infrared spectroscopy (FTIR):}

Figure (3) illustrates FTIR for chitosan and Chitosan-MWCNT nanocomposite, from the figure, it is obvious that, FTIR of chitosan was showed that the intense and wide band at $3220 \mathrm{~cm}^{-1}$ is attributed to the vibration of $-\mathrm{OH}$ group, the characteristic peaks at $1513 \mathrm{~cm}^{-1}$ is due to the vibration of $\mathrm{C}=\mathrm{O}$ while FTIR of was showed the chitosan/CNT composite spectra, the intense bands at $3480 \mathrm{~cm}^{-1}$ and $1040 \mathrm{~cm}^{-1}$ are attributed to the stretching vibration of $\mathrm{N}-\mathrm{H}$ and $\mathrm{C}-\mathrm{O}$ respectively and also $\mathrm{C}=\mathrm{C}$ absorption at the wave number $2344 \mathrm{~cm}^{-1}$. 


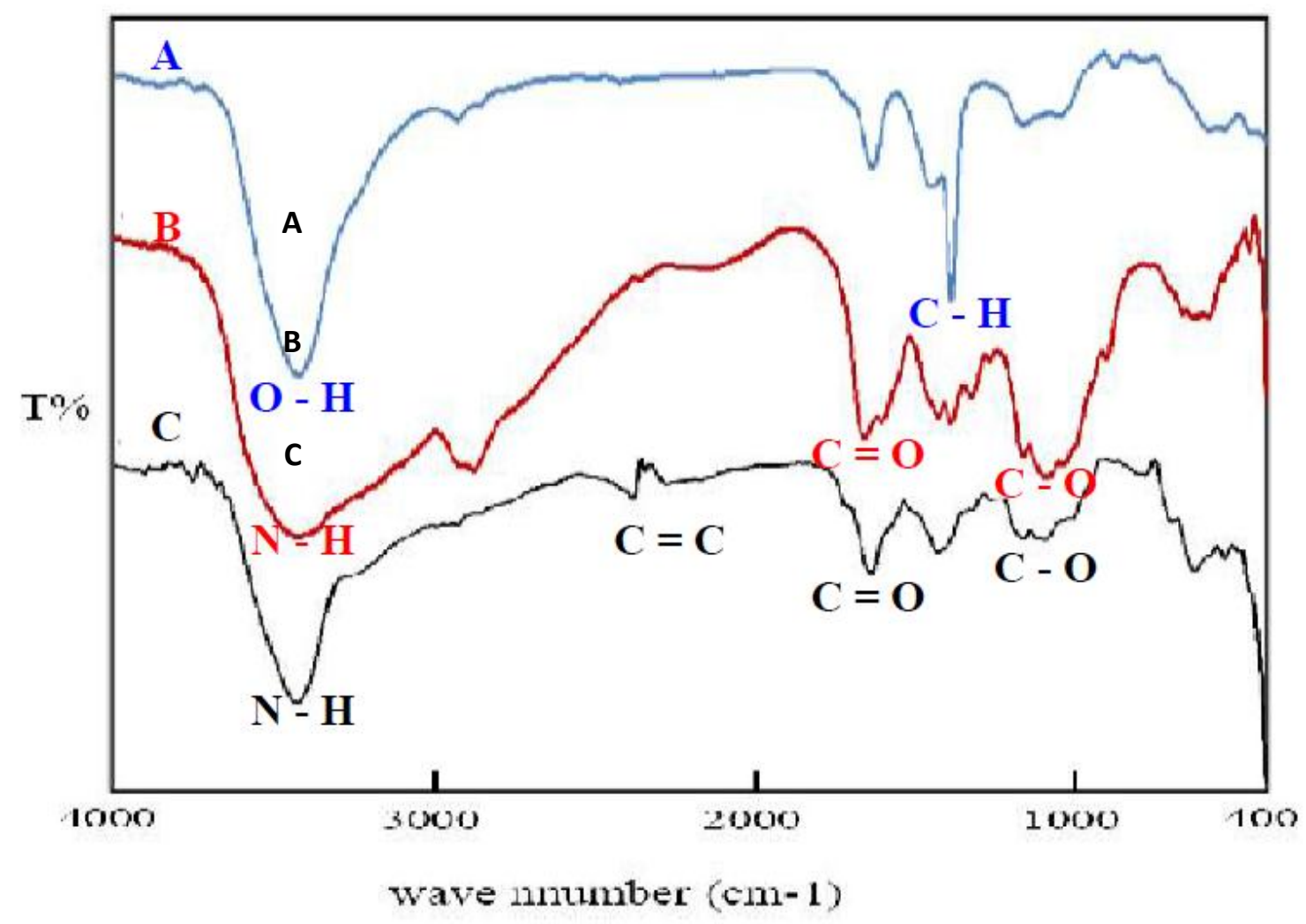

Figure (3): FTIR imaged for A) pure MWCNT, B) modified MWCNT and C) modified MWCNT/Chitosan (100Ch:25CNT) nanocomposite

\subsection{Antimicrobial Activity:}

The antibacterial activities of Ch, MWCNT and Ch-MWCNT nanocomposite were tested against four bacteria by disc diffusion method and the results are shown in Table (1). In general, all the nanocomposites Ch-MWCNT were more active than chitosan or MWCNT and exhibited a good antibacterial activity against the tested Gram positive and Gram negative bacteria. Inhibition zone ranged from 4 to $19 \mathrm{~mm}$ has been observed for tested bacteria. Nanocomposite No.5 (100:50Ch-MWCNT) showed the best inhibitory activity against S. aureus (SA), E. coli (EC) and P. aeruginosa (PA)(inhibition zone 18.2, 14.5 and $19.2 \mathrm{~mm}$, respectively) and No. 4 (100:25 Ch-MWCNT) against MRSA (inhibition zone $19.4 \mathrm{~mm}$ ). Nanocomposite No. 3 (100:10 Ch-MWCNT) had the best activity against $P$. aeruginosa (inhibition zone $20.3 \mathrm{~mm}$ ).

Compared with chitosan or MWCHT, all the Ch-MWCNT nanocomposites showed higher antimicrobial activity. The experiment examines that Ch-MWCNT nanocomposite showed greater antibacterial activity with respecting to increase the concentration towards MERS, S. aureus and $E$. coli when compared to $P$. aeruginosa. The concentration of Ch-MWCNT 100:50 nanocomposite (V: V) show considerable activity toward the four tested microorganisms compare to other concentrations. 
Table 1: Antibacterial activity of chitosan, MWCNT and different concentrations of ChMWCNT nanocomposites against tested pathogenic bacteria by disc diffusion method

\begin{tabular}{|c|c|c|c|c|c|}
\hline \multirow{2}{*}{ No. } & \multirow{2}{*}{$\begin{array}{l}\text { Concentration of Ch- } \\
\text { MWCNT nanocomposite } \\
(\mathrm{mg} / \mathrm{ml})\end{array}$} & \multicolumn{4}{|c|}{ Diameter of inhibition Zone (mm) } \\
\hline & & S. aureus & MRSA & E. coli & P. aeruginosa \\
\hline $1-$ & $100 \mathrm{Ch}$ & $10.70 \pm 0.02$ & $8.80 \pm 0.02$ & $5.90 \pm 0.09$ & $9.51 \pm 0.04$ \\
\hline $2-$ & 100Ch:1CNT & $13.70 \pm 0.08$ & $11.50 \pm 0.05$ & $9.50 \pm 0.04$ & $12.00 \pm 0.11$ \\
\hline $3-$ & 100Ch:5CNT & $14.80 \pm 0.04$ & $12.50 \pm 0.05$ & $10.20 \pm 0.02$ & $15.10 \pm 0.5$ \\
\hline 4- & 100Ch:10CNT & $16.10 \pm 0.06$ & $12.50 \pm 0.04$ & $11.20 \pm 0.11$ & $20.30 \pm 0.6$ \\
\hline $5-$ & 100Ch:25CNT & $17.30 \pm 0.08$ & $18.10 \pm 0.01$ & $12.50 \pm 0.09$ & $17.30 \pm 0.4$ \\
\hline 6- & 100Ch:50CNT & $18.20 \pm 0.05$ & $19.40 \pm 0.06$ & $14.50 \pm 0.08$ & $19.20 \pm 0.10$ \\
\hline 7- & $100 \mathrm{CNT}$ & $8.60 \pm 0.06$ & $7.80 \pm 0.08$ & $4.20 \pm 0.05$ & $7.50 \pm 0.7$ \\
\hline
\end{tabular}

$( \pm \mathrm{SEM}=$ Standard error mean according to (Snedecor and Cochran, 1980).

\subsection{Minimal inhibitory concentrations (MIC):}

The minimum inhibitory concentration (MIC) was regarded the minimal concentration of the ChMWCNT required to completely inhibit bacterial growth. The MIC values range from 0.0625 $\mu \mathrm{g} / \mathrm{ml}$ to $0.5 \mu \mathrm{g} / \mathrm{ml}$. In this test (Table 2), 4 test bacteria Staphylococcus aureus and Methicillinresistant Staphylococcus aureus (MRSA) human pathogen Gram positive, Escherichia coli and $P$. aeruginosa human pathogen gram negative were used.

Table (2) showed that, the MIC of Ch-MWCNT (100:50 Ch-MWCNT) against Gram negative and Gram positive pathogenic bacteria may be estimated between 0.5 and $0.0625 \mu \mathrm{g} / \mathrm{ml}$, and the inhibition effect growth observes in a concentration dependent species. For $S$. aureus, ChMWCNT shows the level of inhibition is high even in high concentration (Table 2). MIC of ChMWCNT against $S$. aureus is examined to be more than $0.50 \mu \mathrm{g} / \mathrm{ml}$ (Table 2). As well as there is no antimicrobial activity in solution free from Ch-MWCNT which used as a vehicle control. This proves that antimicrobial activity is directly related to the Ch-MWCNT.

Ch-MWCNT nanocomposite at 100:50 shows the highest activity against S. aureus and Ps. aeruginosa with an MIC of $0.0625 \mu \mathrm{g} / \mathrm{ml}$. While the MIC for MRSA and E. coli is $0.5 \mu \mathrm{g} / \mathrm{ml}$. The least MIC activity against MRSA and E. coil is $0.25 \mu \mathrm{g} / \mathrm{ml}$ (Table 2). It shows that the extracts nanocomposites are more active against both Gram bacteria positive than Gram negative ones. 
Table 2:The minimum inhibitory concentration $(\mu \mathrm{g} / \mathrm{ml})$ of nanocomposite $100 \mathrm{Ch}: 50 \mathrm{CNT}$ against the test organisms

\begin{tabular}{|l|c|c|c|c|}
\hline \multirow{2}{*}{$\begin{array}{l}\text { Concentration } \\
\text { 100Ch:50CNT } \\
\text { nanocomposite } \\
(\mu \mathrm{g} / \mathrm{ml})\end{array}$} & \multicolumn{4}{|c|}{ MIC $(\mu \mathrm{g} / \mathrm{ml})$} \\
\cline { 2 - 5 } & S. aureus & MRSA & E. coli & P. aeruginosa \\
\cline { 2 - 5 } & 0 & 0 & 0 & 0 \\
\hline $\mathbf{0 . 5}$ & 0 & 0 & + & 0 \\
\hline $\mathbf{0 . 2 5}$ & 0 & +++ & ++ & 0 \\
\hline $\mathbf{0 . 1 2 5}$ & 0 & +++++ & +++ & 0 \\
\hline $\mathbf{0 . 0 6 2 5}$ & & &
\end{tabular}

$(+)$ : Degree of growth

Several mechanisms have been investigated to evaluate the antimicrobial activity of chitosan. The most accepted mechanism is that the positive charge of chitosan combines with negative charge of microbial cell membranes. The interactiontakes place between protonated ammonium group in chitosan and the microbial cell membrane. This leads to promote the osmotic imbalance whereas $\mathrm{CNT}$ has a synergistic effect that damages the microbial membrane in situ in orderto control the microbial growth.

The presence of an outer membrane with strong net negative charge in E. coli becomes obstruct to CNT preventing it from binding to membranes and initiating its antimicrobial activity.

The CNT antimicrobial activity mechanism towards $S$. aureus is simply by direct attachment of CNTs with the bacterial surface proteins. The CNTs emit from the nanocomposite and target the bacteria. Within $24 \mathrm{~h}$ of CNT attachment is leading to the microbial cell membrane lysis (Deokar et al., 2013; Chen et al., 2013). While inhibition mechanism of Gram positive bacterium MRSA is by using higher molecular weight of chitosan which may inhibits the nutrient adsorption. Otherwise Gram negative bacteria are not inhibited by higher molecular weight chitosan. The reason refer to the fact that higher molecular weight chitosan cannot disturb the cell metabolism. The results are appeared to be consequential with the previous studies (Zheng and Zhu, 2003). CNTs have been recently confirmed to their highly antimicrobial activity. Also for their relevant activities are ascribed to the nanodart behaviour with the proposed physical damage mechanism (Kang et. al., 2008). 


\section{4- Conclusion:}

According to the results of this study, it can be concluded that $\mathrm{Ch} / \mathrm{MWCNT}$ - nanocomposite which prepared by modifying chitosan and functionalized CNT. Both of them are mixed with sonication process with composition ratio (100:50) of Ch/CNT. Based on the FTIR results which confirm the presence of the $\mathrm{C}=\mathrm{C}$ absorption at wave length $2344 \mathrm{~cm}^{-1}$. Furthermore TEM results indicate the resulting CNT tubular length morphology.

\section{References:}

Akhavan O., Abdolahad M., Abdi Y. and Mohajerzadeh S. (2011). Silver nanoparticles within vertically aligned multi-wall carbon nanotubes with open tips for antibacterial purposes. JMCh, 21, 387-393.

Akhavan O., Azimirad R., Safad S. and Hasani E. (2011). $\mathrm{CuO} / \mathrm{Cu}(\mathrm{OH})_{2}$ hierarchical nanostructures as bactericidal photocatalysts. J. Mater. Chem., 21,9634-9640.

Amiri A., Zardini H.Z., Shanbedi M., Maghrebi M., Baniadam M. and Tolueinia B. (2012). Efficient method for functionalization of carbon nanotubes by lysine and improved antimicrobial activity and water-dispersion. Mat L, 72, 153-156.

Aslan S., Deneufchatel M., Hashmi S., Li N., Pfefferle L.D., Elimelech M., Pauthe E. and van Tassel P.R. (2012). Carbon nanotube-based antimicrobial biomaterials formed via layer-by-layer assembly with polypeptides. JCIS, 388, 268-273.

Chen H., Wang B., Gao D., Guan M., Zheng L., Ouyang H., Chai Z., Zhao Y. and Feng W. (2013). Broad-spectrum antibacterial activity of carbon nanotubes to human gut bacteria. Small, 9, 2735-2746.

Deokar A.R., Lin L.Y., Chang C.C. and Ling Y.C. (2013). Single-walled carbon nanotube coated antibacterial paper: Preparation and mechanistic study. J. Mater. Chem. B, 1, 2639-2646.

Duttagupta D. S., Jadhav V. M. and Kadam V. J. (2015). Chitosan: a propitious biopolymer for drug delivery. Current Drug Delivery, 12(4), 369-381.

Fair R. J. and Tor Y. (2014). Antibiotics and Bacterial Resistance in the $21^{\text {st }}$ Century. Perspect Medicin Chem., 6, 25-64.

Kang S. Pinault M., Pfefferle L.D. and Elimelech, M. (2007). Single-walled carbon nanotubes exhibit strong antimicrobial activity. Langmuir, 23, 8670-8673.

Kang S., Mauter M.S. and Elimelech M. (2008). Physicochemical determinants of multiwalled carbon nanotube bacterial cytotoxicity. Environ. Sci. Technol., 42, 7528-7534. 
Kang S., Mauter M.S. and Elimelech M. (2008). Physicochemical determinants of multiwalled carbon nanotube bacterial cytotoxicity. Environ. Sci. Technol., 42, 7528-7534.

Lee D. S. and Je J. Y. (2013). Gallic Acid Grafted Chitosan Inhibits Foodborne Pathogens by a Membrane Damage Mechanism. Agric. Food Chem., 61 (26), 65746579 .

Mokhena T. C., Jacobs V. and Luyt A. S. (2015). A review on electrospun biobased polymers for water treatment. eXPRESS Polymer Letters, 9(10), 839-880.

Pandey N., Shukla S. K. and Singh N. B. (2017). Water purification by polymer nanocomposites: an overview. Nanocomposites, 3, 47-66.

Piresa C., Vilelab J. A. P. and Airoldi C. (2014). The effect of Chitin Alkaline Deacetylation at Different Condition on Particle Properties. Procedia Chemistry, 9, $220-225$.

Sambrook J., Fritsch E.F. and Maniatis T. (1989). Molecular cloning: a laboratory Manual, 3. Cold Spring Harbor Laboratory Press, Cold Spring Harbor, N.Y

Sethi S. and Murphy T.F. (2001). Bacterial infection in chronic obstructive pulmonary disease in 2000: A state-of-the-art review. Clin. Microbiol. Rev., 14, 336-363.

Zheng L.Y. and Zhu J.F. (2003). Study on antimicrobial activity of chitosan with different molecular weights.Carbohydr. Polym., 54, 527-530. 


\section{الملخص باللغة العربية}

\section{توصيف وتقييم الأنابيب الكريون النانوية متعددة الجدران و الكيتوزان كعوامل مضادة للبكتريا واسعة المجال}

\section{نهلة التهامى' ، سعديه محمد عيسي ' ، مجدي عطيه محمد" ، نعمت محمد عوض}

1 - بكالوريوس علوم ميكروبيولجى و كيمياء - كلية علوم بنات جامعة عين شمس

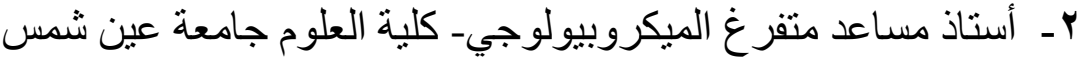

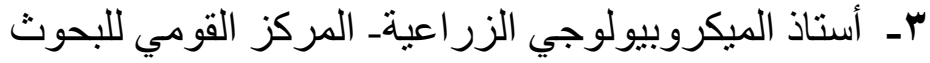

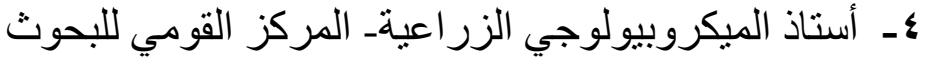

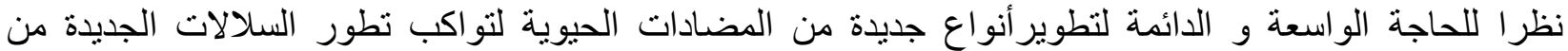

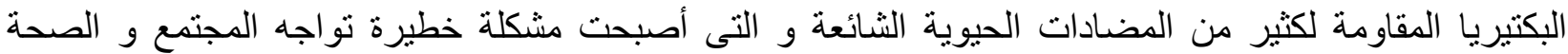

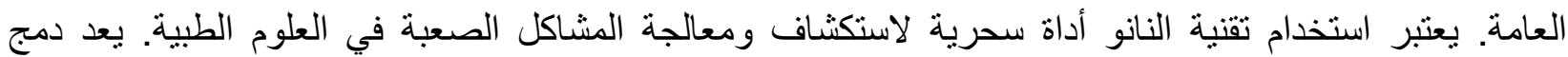

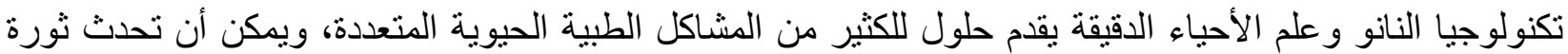
في المجالات الصحية والطبية.

(MWCNTs

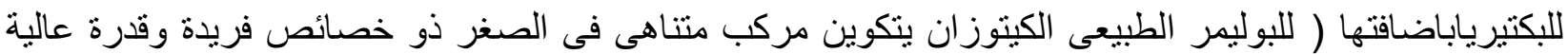

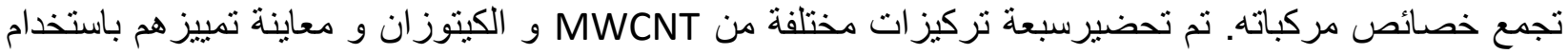
FTIR و TEM لتعيين قابليتهم و قدرتهم على مقاومة اربعة انواع مختلفة من البكتيريا الممرضة.

أظهرت تحليل TEM أن هناك تجانس ملحوظ بين الأنابيب الكربون النانوية متعددة الجدران المعدلة وبوليمرات

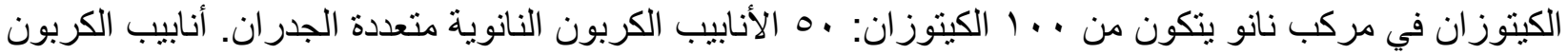

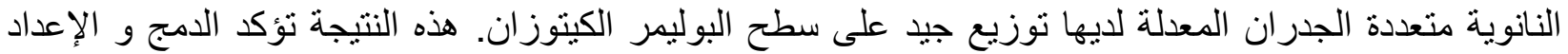

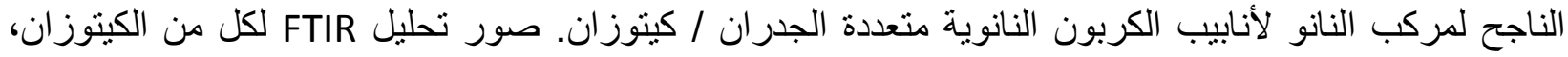
C = أنابيب الكربون النانوية متعددة الجدران المعدلة و مركبهم النانومتري تدل على وجود مجمونة

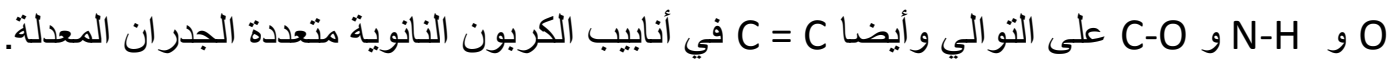
جميع التركيزات للمركبات النانوية الكيتوزان / أنابيب الكربون النانوية متعددة الجدران كانوا أكثر نشاطا من

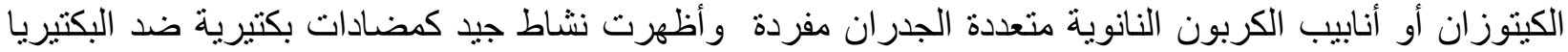

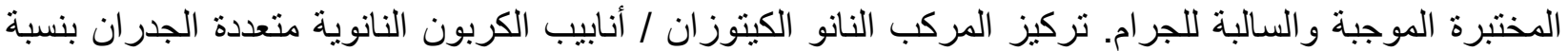

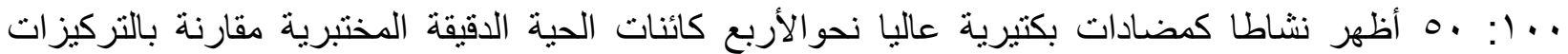

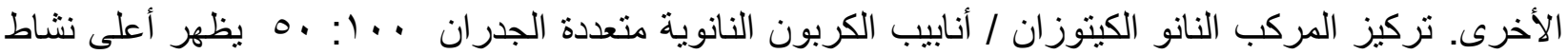
ضد مع أقل تركيز اللتثبيط

P. aeruginosa و Staph.aureus

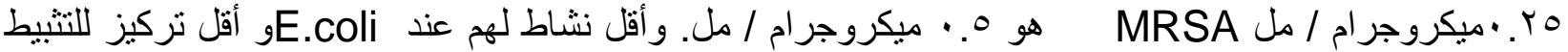

